\title{
Examining the Factors Affecting the Selection of the Recreation Activity Type of University Students
}

\section{Examen de los factores que afectan la selección Del tipo de actividad recreativa de los estudiantes universitarios}

\author{
İbrahim Dalbudak \\ Atabey Vocational School, Isparta University of Applied Sciences, Isparta, Turkey, \\ ORCID ID: https://orcid.org/ 0000-0003-2380-803X
}

\section{Serkan Çelik}

Faculty of Tourism, Recreation Management Department, University of Kâtip Çelebi, Izmir, Turkey, ORCID ID: https://orcid.org/ 0000-0002-6236-8025

\section{Melih Balyan}

Physical Education and Sports Teaching Department, Faculty of Sport Sciences, Ege University, İzmir, Turkey

ORCID ID: https://orcid.org/ 0000-0002-3833-7456

*Correspondence

Email: scelik55@gmail.com
Cite as: 


\section{Summary}

This research was conducted to determine the recreational activity choices of the students studying at various faculties of the university. The main purpose of this study is to determine the factors that affect the selection of recreational activity of university students. A total of 156 students, 98 female and 58 male, studying at various faculties in İzmir Universities, participated in the survey. As the data collection tool, "Personal Information Form" and the scale made by Arslan (2010 and 2012) to measure the factors affecting the selection of the recreational activity type were used. The data obtained were analyzed by using the SPSS 23 program. "T-test", "ANOVA" and "Tukey post hoc" tests were used to obtain statistical results. "Guidance" subdimension mean score values and "general scale" mean score values were higher in women than men $(\mathrm{p}<0.05)$. "Personal suitability" and "environment" sub-dimension mean score values of individuals with an income of 1000 TL and below are higher than individuals with higher income $(\mathrm{p}<0.05)$. A significant difference was observed only in the mean scores of the "guidance" subdimension according to the educational background of the mothers of the individuals $(p<0.05)$. When the mean score values of "personal suitability", "guidance" sub-dimension and "general scale" were examined, it was concluded that the mean score values of individuals whose fathers are primary and high school graduates were higher than those whose fathers were bachelor and master graduates $(\mathrm{p}<0.05)$. Mean scores of "personal suitability", "environment" sub-dimensions and "general scale" were higher in individuals whose family with an income of $1001-2000 \mathrm{TL}$ per month, that is, the lowest income group $(\mathrm{p}<0.05)$. When we look at the "guidance", "environment" sub-dimensions and the general scale, it was concluded that the mean score values of individuals who think that games are a little effective in activities are higher than the mean score values of individuals who think that games in activities are very effective $(p<0.05)$. The opinions of the individuals about "in which faculty the recreation department should be" do not make a difference on the mean score values of the "general scale" and its sub-dimensions. According to the type of recreational activity that individuals do in their leisure time, the mean score values of the "general scale" and its sub-dimensions do not show a significant difference $(p>0.05)$. As a result of the findings, when the factors that affect the selection of the recreational activity type of the students were examined, it was found that the highest factor was "ageappropriateness". The statement with the lowest mean in the scale is "healthy life programs on TV". In addition, it was concluded that the most effective factors in individuals' choices on the recreational activities were that the activities were personally suitable for them and the environment was also suitable.

Keywords: Free Time, University Student, Recreation Activity Selection, Game.

\section{Resumen}

Esta investigación se realizó para determinar las opciones de actividades recreativas de los estudiantes que estudian en varias facultades de la universidad. El objetivo principal de este estudio es determinar los factores que inciden en la selección de actividad recreativa de los estudiantes universitarios. Un total de 156 estudiantes, 98 mujeres y 58 hombres, que estudian en varias facultades de las universidades de İzmir, participaron en la encuesta. Como herramienta de recolección de datos se utilizó el "Formulario de Información Personal" y la escala realizada por Arslan (2010 y 2012) para medir los factores que inciden en la selección del tipo de actividad recreativa. Los datos obtenidos se analizaron mediante el programa SPSS 23. Para obtener los resultados estadísticos se utilizaron las pruebas "T-test", "ANOVA" y "Tukey post hoc". Los valores de puntuación media de la subdimensión de "orientación" y los valores de puntuación media de la "escala general" fueron más altos en las mujeres que en los hombres ( $p<0,05)$. Los valores de puntuación media de las subdimensiones "idoneidad personal" y "medio ambiente" de las personas con un ingreso de 1000 TL y menos son más altos que los de las personas con ingresos más altos $(\mathrm{p}<0.05)$. Se observó una diferencia significativa solo en las puntuaciones medias de la subdimensión "orientación" según el nivel educativo de las madres de los individuos ( $\mathrm{p}<0,05)$. Cuando se examinaron los valores de puntaje promedio de "idoneidad personal", 
subdimensión de "orientación" y "escala general", se concluyó que los valores de puntaje promedio de las personas cuyos padres son graduados de la escuela primaria y secundaria eran más altos que aquellos cuyos padres eran egresados de la escuela primaria y secundaria. graduados de licenciatura y maestría $(\mathrm{p}<0.05$ ). Las puntuaciones medias de las sub-dimensiones de "idoneidad personal", "medio ambiente" y "escala general" fueron más altas en los individuos cuya familia con un ingreso de 1001 - 2000 TL mensuales, es decir, el grupo de ingresos más bajos ( $\mathrm{p}<0,05)$. Cuando miramos las sub-dimensiones de "orientación", "medio ambiente" y la escala general, se concluyó que los valores de puntaje promedio de las personas que piensan que los juegos son un poco efectivos en las actividades son más altos que los valores de puntaje promedio de los individuos que Piensan que los juegos en las actividades son muy efectivos (p $<0.05$ ). Las opiniones de los individuos sobre "en qué facultad debería estar el departamento de recreación" no influyen en los valores de puntuación media de la "escala general" y sus subdimensiones. Según el tipo de actividad recreativa que realizan los individuos en su tiempo libre, los valores de puntuación media de la "escala general" y sus subdimensiones no muestran una diferencia significativa ( $p>0,05$ ). Como resultado de los hallazgos, cuando se examinaron los factores que afectan la selección del tipo de actividad recreativa de los estudiantes, se encontró que el factor más alto fue la "adecuación a la edad". El enunciado con la media más baja de la escala es "programas de televisión sobre vida sana". Además, se concluyó que los factores más efectivos en las elecciones de los individuos sobre las actividades recreativas eran que las actividades fueran personalmente adecuadas para ellos y el entorno también lo era.

Palabras clave: Tiempo libre, estudiante universitario, selección de actividades recreativas, juego.

\section{Introduction}

Due to the decrease in working hours thanks to the increasing technology with the development of the industry, there is an increase in the extra leisure time after the working hours of the people. This phenomenon of leisure time has gradually gained an important place in people's lives today. Leisure time is defined as the time devoted to activities performed freely alone or in groups, depending on the preference of the individual, excluding physiology such as food, sleeping and meeting sexual needs, occupational activities such as family and business life such as some obligatory work in the home (Arslan 1996). This leisure concept created recreational activities. Recreation includes activities that individuals participate voluntarily and make use of their leisure time. These activities are considered as sportive activities, musical activities, games, artistic activities, nature activities, activities requiring skill, social and cultural activities (Kurar and Baltac1, 2014). The development of recreation has taken place in stages from the first civilizations to today (Hazar, 2009). "Rekreasyon" has entered our language from the English word "Recreation". When recreation is considered in this sense, it is the activities people perform with the aim of 'reconstructing - recreating' the physical and mental resources they consume as a result of their work activities (Uğurlu, 2005). Recreation comes from the Latin word 'recreatio' which means regeneration, recreation (Torkildsen, 1999). According to The Macquerie (1987) dictionary, recreation is used as 'regeneration which means physical or mental regeneration after work or regeneration which means relaxation or pleasure' (Jenkins \& Pigram, 2006). Bucher and Bucher (1974) define recreation as 'getting rid of the boredom of daily life and gaining a social personality by interacting with other people by participating in social, cultural and sportive activities that are appropriate for one's self and enjoy doing. Recreation has functions such as increasing the quality of life of individuals of all ages, ensuring the correct use of the body with habits acquired from childhood, and adopting social values as a life philosophy (Uzun et al. 2017). Recreation is the activities that people do in their leisure time other than the time they spend to meet their work and compulsory needs, to realize themselves with volunteer participation and to get away from the troubles of daily life (Türkmen et al. 2013). It is seen that recreational activities performed by individuals in order to make use of their leisure time are classified as active, passive and causative (accompanied by an expert recreator) according to the type of participation. If a sportive activity is given as an example, the fact that an individual plays football is the factor; 
passive participation by an individual watching a football match at home or in a stadium; having football training accompanied by a professional football teacher is a causative participation (Gül, 2014). He examined the concept of recreation in two classes at the point of realizing people's goals and desires with different characteristics. These are active and passive recreation concepts. While active recreation is defined as the sportive activities (football, tennis, nature sports, golf, swimming etc.) where the activities of the individual manifest directly by spending a physical performance, passive recreation is defined as activities such as picnicking, fishing and visiting zoos and botanical gardens (Schwilgin et al.1974). In short, since recreation is very important for individuals, it is seen as an increasing value today. We can say that the factors that are effective in the selection of reactive activities are the types of activities that individuals want to do in their leisure time or participate within the framework of their possibilities. These activities may change according to the characteristics of individuals such as age, economic status, and environmental factors. In the light of these findings, in this study, it was aimed to determine the selection of recreational activities of students studying at different faculties of universities in Izmir.

\section{Methodology}

Research Model

In this study, descriptive and correlational survey methods, which are general survey models, were used.

\section{Forming Volunteer Groups}

Students studying at various faculties and different departments in universities in Izmir in the 2020-2021 academic year were included in the study. They participated in the study voluntarily.

\section{Data Collection Techniques}

As data collection techniques, Personal Information Form and Recreative activity selection scale has been used.

\section{Personal Information Form}

In obtaining the data, the "Personal Information Form" including the questions prepared by the researcher regarding demographic characteristics and including gender, age, educational background of the mother and father, economic status of the family, income status of the family, game, leisure activity and at which faculty recreation department should be was used.

\section{Recreative Activity Selection Scale}

"Personal Information Form" and the data regarding the factors affecting the selection of the recreational activity type were obtained by using the measurement tool adapted to Turkish by Arslan (2010 and 2012).

\section{Distribution of Demographic Features}

Table 1. Demographic Distribution of the Individuals Participating in the Study

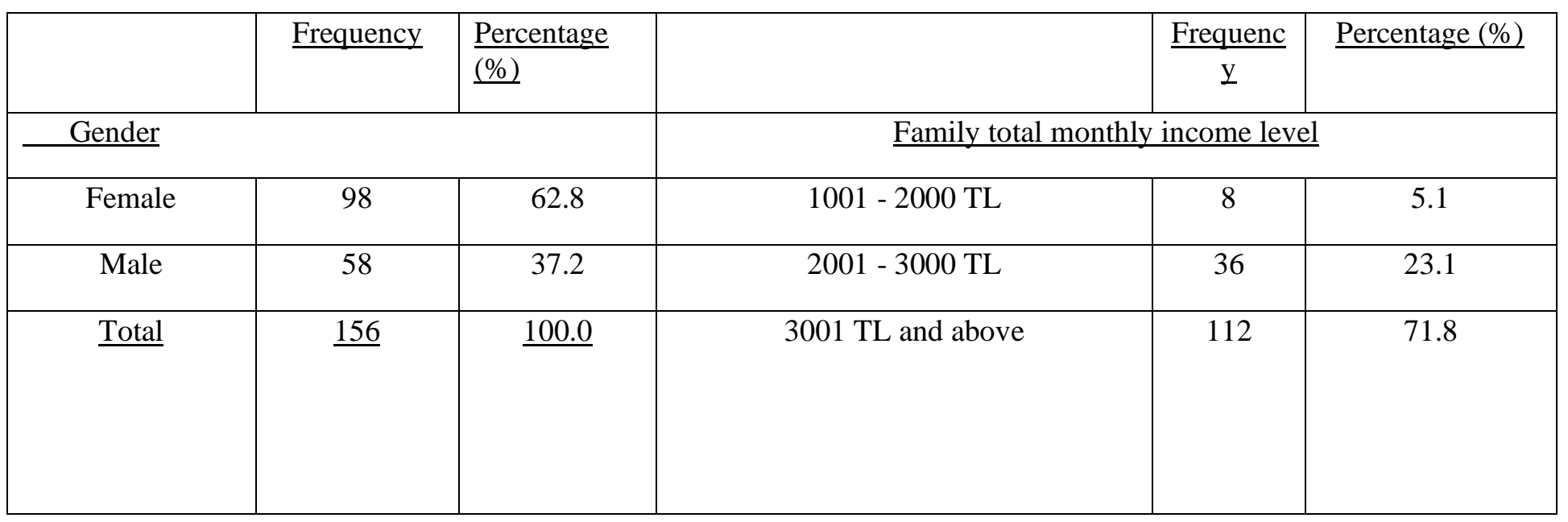




\begin{tabular}{|c|c|c|c|c|c|}
\hline \multicolumn{3}{|c|}{ Income level } & Total & 156 & 100.0 \\
\hline $\begin{array}{l}1000 \mathrm{TL} \text { and } \\
\text { below }\end{array}$ & 110 & 70.5 & \multicolumn{3}{|c|}{ Which faculty would you like the recreation department to be in? } \\
\hline $1001-1500 \mathrm{TL}$ & 22 & 14.1 & Faculty of Sport Sciences & 29 & 18.6 \\
\hline $\begin{array}{l}1501 \mathrm{TL} \text { and } \\
\text { above }\end{array}$ & 24 & 15.4 & Faculty of Tourism & 127 & 81.4 \\
\hline$\underline{\text { Total }}$ & 156 & 100.0 & Total & 156 & 100.0 \\
\hline \multicolumn{3}{|l|}{ Age group } & \multicolumn{3}{|c|}{ How effective are games in recreational activities? } \\
\hline $18-20$. & \multicolumn{2}{|r|}{20.5} & Very effictive & 129 & 82,7 \\
\hline $21-23$ & 96 & 61.6 & Slightly effective & 27 & 17.3 \\
\hline $24-26$ & 18 & 11,5 & Total & 156 & 100.0 \\
\hline 27 and above & 10 & 6.4 & \multicolumn{3}{|c|}{ What kind of recreational activities do you do in your leisure time? } \\
\hline Total & 156 & 100.0 & Sports & 50 & 32,1 \\
\hline \multicolumn{3}{|c|}{ Mother's Educational Background } & Other activities & 106 & 67.9 \\
\hline Illiterate & 4 & 2.6 & Total & $\underline{156}$ & 100.0 \\
\hline $\begin{array}{l}\text { Primary } \\
\text { Education }\end{array}$ & 64 & 41.0 & & & \\
\hline High School & 48 & 30.8 & & & \\
\hline University & 38 & 24.3 & & & \\
\hline Master Degree & 2 & 1.3 & & & \\
\hline$\underline{\text { Total }}$ & $\underline{156}$ & $\underline{100.0}$ & & & \\
\hline \multicolumn{3}{|c|}{ Father's Educational Background } & & & \\
\hline $\begin{array}{c}\text { Primary } \\
\text { Education }\end{array}$ & 56 & 35.9 & & & \\
\hline High School & 42 & 26,9 & & & \\
\hline University & 54 & 34,6 & & & \\
\hline
\end{tabular}




\begin{tabular}{|c|c|c|c|c|c|}
\hline Master Degree & 4 & 2.6 & \multicolumn{3}{|c|}{} \\
\hline$\underline{\text { Total }}$ & $\underline{156}$ & $\underline{100.0}$ & & & \\
& & & & & \\
\hline
\end{tabular}

\section{Relations between Demographic Findings}

\section{Recreation (leisure time) Scale}

Scoring $\rightarrow$ strongly agree: 5 , agree: 4 , neither agree nor disagree: 3 , disagree: 2 , strongly disagree:

1

\section{Questions of the Factors Affecting the Selection of the Recreative Activity Type \\ Sub-Dimensions}

Personal suitability: 1-2-3-4-5. items

Guidance: 6-7-8. items

Environment: 9-10. Items

Table 2. Factors Affecting The Selection of Recreational Activity Type

\begin{tabular}{|c|c|c|c|c|c|c|c|c|c|}
\hline \multirow{3}{*}{ Dimensions } & & \multirow{3}{*}{ 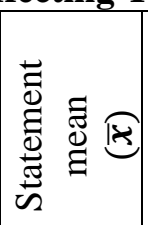 } & \multirow{3}{*}{ 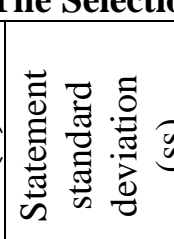 } & \multirow{2}{*}{\multicolumn{6}{|c|}{ Descriptive summary statistics }} \\
\hline & \multirow{2}{*}{ Statements } & & & & & & & & \\
\hline & & & & $\bar{x}$ & SD & Min & Max. & Skewness & Kurtosis \\
\hline \multirow{5}{*}{$\begin{array}{l}\text { Personal } \\
\text { suitability }\end{array}$} & Suitable for age & 4,4487 & 0,8446 & \multirow{5}{*}{4,1962} & \multirow{5}{*}{0,4472} & \multirow{5}{*}{2,20} & \multirow{5}{*}{5,00} & \multirow{5}{*}{$-0,930$} & \multirow{5}{*}{1,889} \\
\hline & Suitable for talents & 3,8782 & 0,9459 & & & & & & \\
\hline & High cost & 3,8718 & 0,8402 & & & & & & \\
\hline & Suitable time & 4,3718 & 0,7203 & & & & & & \\
\hline & Suitable location & 4,4103 & 0,6103 & & & & & & \\
\hline \multirow{3}{*}{ Guidance } & $\begin{array}{c}\text { Wellness programs on } \\
\text { TV }\end{array}$ & 2,3397 & 1,0625 & \multirow{3}{*}{3,3697} & \multirow{3}{*}{0,6274} & \multirow{3}{*}{1,33} & \multirow{3}{*}{5,00} & \multirow{3}{*}{$-0,418$} & \multirow{3}{*}{1,840} \\
\hline & Doctor Recommendation & 3,8141 & 0,8096 & & & & & & \\
\hline & $\begin{array}{l}\text { Recommendations of } \\
\text { former participants }\end{array}$ & 3,9551 & 0,7898 & & & & & & \\
\hline \multirow{2}{*}{ Environment } & $\begin{array}{l}\text { Feeling comfortable in } \\
\text { the environment }\end{array}$ & 4,4231 & 0,9707 & \multirow{2}{*}{4,1891} & \multirow{2}{*}{0,5885} & \multirow{2}{*}{2,50} & \multirow{2}{*}{5,00} & \multirow{2}{*}{$-0,654$} & \multirow[t]{2}{*}{$-0,136$} \\
\hline & Accompanying friends & 3,9551 & 0,7564 & & & & & & \\
\hline \multicolumn{4}{|c|}{ Overall scale } & 3,9468 & 0,3960 & 2,60 & 5,00 & $-0,473$ & 1,187 \\
\hline
\end{tabular}

When the factors that affect the selection of the recreational activity type were examined in the table above, the statement with the highest mean $(\bar{x}=4,4487)$ was found to be "suitable for age". $2,6 \%$ of students replied "strongly disagree", $7,7 \%$ of them replied "neither agree nor disagree", $29,5 \%$ of them replied "agree" and $60,3 \%$ of them replied "strongly agree" to this statement in the form. The statement with the lowest mean in the scale $(\bar{x}=2.3397)$ was "Healthy life programs on TV". To this statement, $23.1 \%$ of the students replied "strongly disagree", $37,8 \%$ of them replied "disagree", $25,0 \%$ of them replied "neither agree nor disagree", $10,3 \%$ of them replied "agree" and 3,8\% of them replied "I strongly agree". The mean of the "personal suitability" subdimension is 4,1962 , the "guidance" sub-dimension is 3,3697, and the "environment" subdimension is 4,1891 . The general mean of the scale was found to be 3.9468. Since the skewness 
and kurtosis values of the sub-dimensions and the general scale are between -2 and +2 , they provide the normal distribution assumption. In addition, according to the sub-dimension means, it can be stated that the most effective factors for individuals in choosing their recreational activities are that the activities are personally suitable and the environment is also suitable.

Interpreting the relationship between the general scale and its sub-dimensions with the Pearson correlation coefficient

Table 3. Pearson Correlation Coefficient Values

\begin{tabular}{|c|c|c|c|l|}
\hline & $\begin{array}{c}\text { Overall } \\
\text { scale }\end{array}$ & Personal suitability & Guidance & Environment \\
\hline Overall scale & 1,000 & $\begin{array}{c}0,788^{* *} \\
(0,000)\end{array}$ & $\begin{array}{c}0,685^{* *} \\
(0,000)\end{array}$ & $\begin{array}{l}0,773^{* *} \\
(0,000)\end{array}$ \\
\hline Personal suitability & $\begin{array}{c}0,788^{* *} \\
(0,000)\end{array}$ & 1,000 & 0,157 & $0,500^{* *}$ \\
& $0,0,052)$ & 1,000 & $0,406^{* *}$ \\
\hline Guidance & $\begin{array}{c}0,685^{* *} \\
(0,000)\end{array}$ & $\begin{array}{c}0,157 \\
(0,052)\end{array}$ & $0,000)$ \\
\hline Environment & $\begin{array}{c}0,773^{* *} \\
(0,000)\end{array}$ & $\begin{array}{c}0,500^{* *} \\
(0,000)\end{array}$ & $\begin{array}{c}0,406^{* *} \\
(0,000)\end{array}$ & 1,000 \\
\hline
\end{tabular}

* The correlation is significant at the 0.01 level.

- Looking at the table, there is a statistically significant and same-directional relationship between the "general scale" and all its sub-dimensions at $99 \%$ confidence level. As the mean score of any sub-dimension increases, the general scale mean score increases, or while the mean score of any sub-dimension decreases, the general scale mean score also decreases.

- There is no significant relationship between "personal suitability" sub-dimension mean scores and "guidance" sub-dimension mean scores ( $\mathrm{p}=0.052)$ at $99 \%$ confidence level, it was concluded that there is a significant and same-direction relationship between "Personal suitability" sub-dimension mean scores and "environment" sub-dimension mean scores $(\mathrm{p}=0.000)$ at $99 \%$ confidence level.

- It is concluded that there is a correlation between the mean scores of the "guidance" subdimension and the mean scores of the "environment" sub-dimension $(\mathrm{p}=0.000)$ at the 99\% confidence level.

Cronbach's Alpha value of the general scale consisting of 10 statements was found to be $\alpha=0.806$ and it is quite consistent and reliable.

\section{Distribution of mean scores of the general scale and its sub-dimensions according to demographic variables}

In the tables below, the distribution of the general scale and its sub-dimensions according to demographic variables and summary statistics are shown. Since the scale and sub-dimension mean scores provide the normal distribution assumption, the difference between the means of two independent groups was tested with the "t-test", and the difference between three or more group means was tested by "one-way analysis of variance (ANOVA)". "Tukey post hoc" test was used to determine which groups caused the significant difference. The study was conducted at $\% 95$ significance level.

Table 4. The Results of Students' Selection of Recreational Activities by Gender 


\begin{tabular}{|l|c|c|c|c|c|}
\hline Gender & & $\begin{array}{c}\text { Personal } \\
\text { Suitability }\end{array}$ & Guidance & $\begin{array}{c}\text { Environm } \\
\text { ent }\end{array}$ & $\begin{array}{c}\text { Overall } \\
\text { Scale }\end{array}$ \\
\hline \multirow{2}{*}{ Female } & Mean & 4,2388 & 3,5000 & 4,2296 & 4,0153 \\
\cline { 2 - 6 } & St. Dev. & 0,4794 & 0,5483 & 0,5884 & 0,4018 \\
\hline Male & Mean & 4,1241 & 3,1494 & 4,1207 & 3,8310 \\
\cline { 2 - 6 } & St. Dev. & 0,3798 & 0,6929 & 0,5872 & 0,3604 \\
\hline p- value & 0,122 & $0.001^{*}$ & 0,265 & $0.005^{*}$ \\
& & & & & \\
\hline
\end{tabular}

Individuals" "personal suitability" and "environment" sub-dimension mean score values do not differ significantly according to their gender. "Guidance" sub-dimension mean score values and "General scale" mean score values were higher in females than males.

Table 5. The Results of Students' Selection of Recreational Activities by Income Level

\begin{tabular}{|l|c|c|c|c|c|}
\hline Income level & & $\begin{array}{c}\text { Personal } \\
\text { Suitability }\end{array}$ & Guidance & Environment & $\begin{array}{c}\text { Overall } \\
\text { scale }\end{array}$ \\
\hline \multirow{2}{*}{$\begin{array}{l}\text { 1000 TL and } \\
\text { below }\end{array}$} & Mean & 4,2964 & 3,4273 & 4,3045 & 4,0373 \\
\cline { 2 - 6 } & St. Dev. & 0,3498 & 0,6576 & 0,5422 & 0,3563 \\
\hline \multirow{2}{*}{$\mathbf{1 0 0 1}$ - 1500 TL } & Mean & 3,9818 & 3,3333 & 3,9091 & 3,7727 \\
\cline { 2 - 6 } & St. Dev. & 0,7481 & 0,4364 & 0,6480 & 0,4939 \\
\hline $\begin{array}{l}\text { 1501 TL and } \\
\text { above }\end{array}$ & Mean & 3,9333 & 3,1389 & 3,9167 & 3,6917 \\
\cline { 2 - 6 } & St. Dev. & 0,3045 & 0,5972 & 0,5835 & 0,3105 \\
\hline \multirow{2}{*}{ p- value } & $0,000 *$ & 0,119 & $0,001^{*}$ & $0,000^{*}$ \\
\hline
\end{tabular}

According to the income levels of individuals, the "guidance" sub-dimension mean score values do not differ significantly. In addition, "personal suitability" and "environment" sub-dimension mean score values of individuals with an income of $1000 \mathrm{TL}$ and below are higher than the individuals with higher income. "General scale" mean scores were seen lowest in individuals with the income of $1501 \mathrm{TL}$ and above, and the highest in individuals with an income of $1000 \mathrm{TL}$ and below. The general scale mean scores decrease as the income level rises.

Table 6. The Results of Students' Selection of Recreational Activities by Age Group

\begin{tabular}{|c|c|c|c|c|c|}
\hline Age group & & $\begin{array}{c}\text { Personal } \\
\text { Suitability }\end{array}$ & Guidance & Environment & $\begin{array}{c}\text { Overall } \\
\text { scale }\end{array}$ \\
\hline \multirow{2}{*}{$\mathbf{1 8 - 2 0 .}$} & Mean & 4,2854 & 3,0417 & 4,3073 & 3,8945 \\
\cline { 2 - 6 } & St. Dev. & 0,5115 & 0,3762 & 0,5729 & 0,2889 \\
\hline \multirow{2}{21-23}{} & Mean & 4,1000 & 3,4410 & 4,0313 & 3,8266 \\
\cline { 2 - 6 } & St. Dev. & 0,3212 & 0,6727 & 0,5526 & 0,4358 \\
\hline
\end{tabular}




\begin{tabular}{|c|c|c|c|c|c|}
\hline \multirow{2}{24-26}{} & Mean & 4,0000 & 3,3704 & 4,0556 & 3,8222 \\
\cline { 2 - 6 } & St. Dev. & 0,0970 & 0,5928 & 0,5659 & 0,2045 \\
\hline \multirow{2}{*}{$\begin{array}{c}\mathbf{2 7} \text { and } \\
\text { above }\end{array}$} & Mean & 4,0000 & 3,7333 & 3,8000 & 3,8800 \\
\cline { 2 - 6 } & St. Dev. & 0,2666 & 0,5164 & 0,6324 & 0,3084 \\
\hline \multirow{2}{*}{ p- value } & $0,012^{*}$ & $0,003 *$ & $0,008^{*}$ & 0,064 \\
& & & & & \\
\hline
\end{tabular}

"General scale" mean scores do not differ significantly according to the age groups of individuals. However, there are significant differences in sub-dimensions. "Personal suitability" subdimension mean score values were found to be higher in individuals aged between 18 and 20 years than older individuals. "Guidance" sub-dimension mean score values were highest in individuals aged 27 and above, and the lowest in individuals aged 18-20. "Environment" subdimension mean score values were highest in individuals between the ages of 18 and 20 and the lowest in individuals aged 27 years and above.

Table 7. The Results of Students' Selection of Recreational Activities by Educational Background of the Mother

\begin{tabular}{|c|c|c|c|c|c|}
\hline $\begin{array}{l}\text { Mother's } \\
\text { Educationa } \\
\text { I } \\
\text { Backgroun } \\
\text { d }\end{array}$ & & $\begin{array}{c}\text { Personal } \\
\text { Suitability }\end{array}$ & Guidance & Environment & $\begin{array}{c}\text { Overall } \\
\text { scale }\end{array}$ \\
\hline \multirow[t]{2}{*}{ Illiterate } & Mean & 4,5000 & 3,8333 & 4,0000 & 4,2000 \\
\hline & St. Dev. & 0,3464 & 0,5773 & 0,0000 & 0,3464 \\
\hline \multirow{2}{*}{$\begin{array}{l}\text { Primary } \\
\text { Education }\end{array}$} & Mean & 4,3031 & 3,5469 & 4,2578 & 4,0672 \\
\hline & St. Dev. & 0,5297 & 0,4764 & 0,6606 & 0,4306 \\
\hline \multirow{2}{*}{$\begin{array}{l}\text { High } \\
\text { School }\end{array}$} & Mean & 4,1333 & 3,4444 & 4,1250 & 3,9250 \\
\hline & St. Dev. & 0,3720 & 0,5114 & 0,3927 & 0,2786 \\
\hline \multirow[t]{2}{*}{ Bachelor } & Mean & 4,0632 & 2,9649 & 4,1316 & 3,7474 \\
\hline & St. Dev. & 0,3482 & 0,7895 & 0,6746 & 0,3991 \\
\hline \multirow{2}{*}{$\begin{array}{l}\text { Master } \\
\text { Degree }\end{array}$} & Mean & 4,2000 & 2,6667 & 5,0000 & 3,9000 \\
\hline & St. Dev. & 0,0000 & 0,0000 & 0,0000 & 0,0000 \\
\hline \multicolumn{2}{|l|}{ p- value } & 0,051 & $0,000^{*}$ & 0,198 & 0,101 \\
\hline
\end{tabular}

A significant difference was observed only in the "guidance" sub-dimension mean score values according to the education levels of the individuals" mothers. Accordingly, the "guidance" subdimension mean score values decrease as the educational background of the mother increases. The highest mean score was observed in individuals whose mother was illiterate, the second highest mean score was in individuals whose mother was primary school graduate, the third highest mean score was in individuals whose mother was high school graduate, the fourth highest mean score was in individuals whose mother was bachelor graduate, and the lowest mean score was in individuals whose mother was master degree graduate. 
Table 8. The Results of Students' Selection of Recreational Activities by Educational Background of Father

\begin{tabular}{|l|c|c|c|c|c|}
\hline \multicolumn{1}{|c|}{$\begin{array}{c}\text { Father's } \begin{array}{c}\text { Educatiol } \\
\text { Backgro } \\
\text { und }\end{array} \\
\text { Primary } \\
\text { Education }\end{array}$} & Mean & Suitability & Guidance & Environmet & $\begin{array}{c}\text { Overall } \\
\text { scale }\end{array}$ \\
\cline { 2 - 6 } & St. Dev. & 0,3746 & 0,6333 & 0,5374 & 0,3615 \\
\hline $\begin{array}{l}\text { High } \\
\text { School }\end{array}$ & Mean & 4,3048 & 3,3651 & 4,1905 & 4,0000 \\
\cline { 2 - 6 } & St. Dev. & 0,2971 & 0,6898 & 0,6143 & 0,3615 \\
\hline \multirow{2}{*}{ Bachelor } & Mean & 3,9926 & 3,2222 & 4,0741 & 3,7778 \\
\cline { 2 - 6 } & St. Dev. & 0,5079 & 0,5339 & 0,5940 & 0,3810 \\
\hline $\begin{array}{l}\text { Master } \\
\text { Degree }\end{array}$ & Mean & 3,7000 & 2,8333 & 4,2500 & 3,5500 \\
\cline { 2 - 6 } & St. Dev. & 0,5773 & 0,1924 & 0,8660 & 0,4041 \\
\hline p- value & & $0,000^{*}$ & $0,012 *$ & 0,273 & $0,000^{*}$ \\
\hline
\end{tabular}

There is no significant difference between the mean score values of the "environment" subdimension according to the education background of the fathers of the individuals. When the mean score values of "personal suitability", "guidance" sub-dimension and "general scale" were examined, it was concluded that the mean score values of individuals whose fathers are primary and high school graduates are higher than those whose fathers are bachelor and master degree graduates.

Table 9. The Results of Students' Selection of Recreational Activities by Total Monthly Income Level of the Family

\begin{tabular}{|l|c|c|c|c|c|}
\hline $\begin{array}{l}\text { Total monthly } \\
\text { income level of } \\
\text { family }\end{array}$ & & $\begin{array}{c}\text { Personal } \\
\text { Suitability }\end{array}$ & Guidance & Environment & Overall scale \\
\hline \multirow{2}{*}{$\mathbf{1 0 0 1}$ - 2000 TL } & Mean & 4,7000 & 3,8333 & 4,7500 & 4,4500 \\
\cline { 2 - 6 } & St. Dev. & 0,3545 & 0,7766 & 0,2672 & 0,4309 \\
\hline \multirow{2}{*}{$\mathbf{2 0 0 1}$ - 3000 TL } & Mean & 4,1889 & 3,2593 & 4,2500 & 3,9222 \\
\cline { 2 - 6 } & St. Dev. & 0,3205 & 0,6624 & 0,5140 & 0,3304 \\
\hline \multirow{3}{*}{$\begin{array}{l}\text { 3001 TL and } \\
\text { above }\end{array}$} & Mean & 4,1625 & 3,3720 & 4,1295 & 3,9187 \\
\cline { 2 - 6 } & St. Dev. & 0,4684 & 0,5948 & 0,6068 & 0,3919 \\
\hline
\end{tabular}




\begin{tabular}{|l|l|l|l|l|}
\hline p- value & $0,004 *$ & 0,064 & $0,011^{*}$ & $0,001^{*}$ \\
& & & & \\
\hline
\end{tabular}

There is no significant difference between the mean score values of the "guidance" sub-dimension according to the monthly total income levels of the families of the individuals. The mean scores of "personal suitability", "environment" sub-dimensions and "general scale" were higher in individuals whose total monthly income level of family was 1001-2000 TL per month, that is, the lowest group than other individuals.

Table 10. The Results of Students' Selection of Recreational Activities by Recreation Department

\begin{tabular}{|l|c|c|c|c|c|}
\hline $\begin{array}{l}\text { Which faculty would } \\
\text { you like the recreation } \\
\text { department to be in? }\end{array}$ & & $\begin{array}{c}\text { Personal } \\
\text { Suitability }\end{array}$ & Guidance & $\begin{array}{c}\text { Environ } \\
\text { ment }\end{array}$ & $\begin{array}{c}\text { Overall } \\
\text { scale }\end{array}$ \\
\hline $\begin{array}{l}\text { Faculty of Sport } \\
\text { Sciences }\end{array}$ & Mean & 4,2069 & 3,2644 & 4,0862 & 3,9000 \\
& St. Dev. & 0,3604 & 0,4398 & 0,5356 & 0,3162 \\
\hline Faculty of Tourism & Mean & 4,1937 & 3,3937 & 4,2126 & 3,9575 \\
& & & & & \\
\cline { 2 - 6 } & St. Dev. & 0,4659 & 0,6619 & 0,5993 & 0,4124 \\
\hline p- value & & 0,887 & 0,318 & 0,298 & 0,482 \\
\hline
\end{tabular}

The opinions of the individuals about "which faculty the recreation department should be in" do not make a difference on the mean score values of the "general scale" and its sub-dimensions.

Table 11. The Results of Students' Selection of Recreational Activities by Game Selection

\begin{tabular}{|c|c|c|c|c|c|}
\hline $\begin{array}{c}\text { How effective are } \\
\text { games in } \\
\text { recreational } \\
\text { activities? }\end{array}$ & $\begin{array}{c}\text { Personal } \\
\text { Suitability }\end{array}$ & Guidance & $\begin{array}{c}\text { Environ } \\
\text { ment }\end{array}$ & $\begin{array}{c}\text { Overall } \\
\text { scale }\end{array}$ \\
& & & & & \\
\hline
\end{tabular}




\begin{tabular}{|l|c|c|c|c|c|}
\hline Very efficient & Mean & 4,1767 & 3,2972 & 4,1202 & 3,9016 \\
\cline { 2 - 6 } & St. Dev. & 0,4434 & 0,6012 & 0,5921 & 0,3915 \\
\hline Slightly effective & Mean & 4,2889 & 3,7160 & 4,5185 & 4,1630 \\
& St. Dev. & 0,4618 & 0,6451 & 0,4489 & 0,3487 \\
\hline p- value & 0,237 & $0,001^{*}$ & $0,001^{*}$ & $0,002^{*}$ \\
\hline
\end{tabular}

Individuals" opinions about "how effective the games in recreational activities are", did not show any effect on the sub-dimension mean score values of "personal suitability". When the "guidance", "environment" sub-dimensions and the general scale were examined, it was concluded that the mean score values of the individuals who think that the games in the activities are slightly effective are higher than the mean score values of the individuals who think that the games in the activities are very effective.

Table 12. The Results of Students' Selection of Recreational Activities by Recreation They Did in Their Leisure Time

\begin{tabular}{|l|c|c|c|c|c|}
\hline $\begin{array}{l}\text { What kind of } \\
\text { recreational } \\
\text { activities do you do } \\
\text { in your leisure } \\
\text { time? }\end{array}$ & $\begin{array}{c}\text { Personal } \\
\text { Suitability }\end{array}$ & Guidance & $\begin{array}{c}\text { Environ } \\
\text { ment }\end{array}$ & $\begin{array}{c}\text { Overall } \\
\text { scale }\end{array}$ \\
\hline Sports & Mean & 4,2240 & 3,3067 & 4,2000 & 3,9440 \\
\cline { 2 - 7 } & St. Dev. & 0,3347 & 0,4754 & 0,6227 & 0,3091 \\
\hline Other activities & Mean & 4,1830 & 3,3994 & 4,1840 & 3,9481 \\
\cline { 2 - 7 } & St. Dev. & 0,4923 & 0,6876 & 0,5745 & 0,4323 \\
\hline p- value & 0,595 & 0,391 & 0,874 & 0,952 \\
\hline
\end{tabular}

According to the type of recreational activity individuals do in their leisure time, the mean score values of the "general scale" and its sub-dimensions do not show a significant difference.

\section{Discussion and Conclusion}

Within the scope of the research, it was aimed to determine the recreational activity choices of the students studying at various faculties in universities in Izmir.

Individuals" "personal suitability" and "environment" sub-dimension mean score values do not differ significantly according to their gender ( $p>0.05)$. "guidance" sub-dimension mean score values and "general scale" mean score values were higher in females than males $(p<0.05)$. In the study conducted by Sonmezoglu et al. (2014), it was found that female participants had more leisure time satisfaction than men. We can say that gender is an important limiting factor in determining the selection of recreational activities. We can state that the reason why women at the university are in the forefront of recreational activities compared to men is that women give more importance to themselves and are more social than men. We can say that the expectations for personal suitability and environment sub-dimensions to be the same are also similar. It supports the study we have done, as it is close to the study we have done.

According to the income levels of individuals, the "guidance" sub-dimension mean score values do not differ significantly ( $p>0.05)$. In addition, "personal suitability" and "environment" sub- 
dimension mean score values of individuals with an income of $1000 \mathrm{TL}$ and below are higher than individuals with higher income $(\mathrm{p}<0.05)$. "General scale" mean scores were seen lowest in individuals with the income of $1501 \mathrm{TL}$ and above, and the highest in individuals with an income of $1000 \mathrm{TL}$ and below. The general scale mean scores decrease as the income level rises. They are inversely proportional. We can state that as the economic level of individual's increases, their selection of recreation activities decreases. No findings were obtained to support our study.

"General scale" mean scores do not differ significantly according to the age groups of individuals $(p>0.05)$. However, there are significant differences in sub-dimensions $(p<0.05)$. "Personal suitability" sub-dimension mean score values were found to be higher in individuals aged between 18 and 20 years than older individuals. "Guidance" sub-dimension mean score values were highest in individuals aged 27 and above, and the lowest in individuals aged 18-20. "Environment" sub-dimension mean score values were highest in individuals between the ages of 18 and 20 and the lowest in individuals aged 27 years and above. Recreation has functions such as increasing the life quality of individuals of all ages, ensuring the correct use of the body with habits acquired from childhood, and adopting social values as a life philosophy (Uzun et all. 2017). In short, it is seen that recreation is very important for individuals of all ages.

A significant difference was observed only in the mean scores of the "guidance" sub-dimension according to the educational background of the individuals' mothers $(\mathrm{p}<0.05)$. Accordingly, the "guidance" sub-dimension mean score values decrease as the education level of the mother increases. The highest mean score was observed in individuals whose mother was illiterate, the second highest mean score was in individuals whose mother was primary school graduate, the third highest mean score was in individuals whose mother was high school graduate, the fourth highest mean score was in individuals whose mother was bachelor graduate, and the lowest mean score was in individuals whose mother was master degree graduate. Education background seems to be effective on guidance. The lower the education level is, the higher the guidance effect is. There is no significant difference between other mean score values according to educational background ( $p>0.05$ ). The life quality of those who actively participate in recreational activities has improved compared to the past (Mannel, 2007). Therefore, we can say that the educational background of the individuals is not effective since they will increase the life quality and provide a healthy long life by participating in recreational activities regardless of their educational background.

There is no significant difference between the mean score values of the "environment" subdimension according to the educational background of the individuals' fathers ( $p>0.05)$. We see that educational backgrounds have no effect on the environment. We can say that every individual agrees on the expectations from the environment. When the mean score values of "personal suitability", "guidance" sub-dimension and "general scale" were examined, it was concluded that the mean score values of individuals whose fathers were primary and high school graduates were higher than those whose fathers were bachelor and master degree graduates $(\mathrm{p}<0.05)$. As the educational level decreases in the selection of recreation activities, the scores of "personal suitability", "guidance" sub-dimensions and "general scale" increase. We can state that the educational background has an effect on the selection of recreation activities.

There is no significant difference between the mean scores of the "guidance" sub-dimension according to the monthly total income levels of individuals' families ( $p>0.05)$. The mean scores of "personal suitability", "environment" sub-dimensions and "general scale" were higher in individuals whose family income was 1001 - $2000 \mathrm{TL}$ per month, that is, the lowest group $(\mathrm{p}<0.05)$. In the selection of recreation activities, as the income level of the person decreases, the "personal suitability", "environment" sub-dimensions and "general scale" scores increase. We can state that the income level affects the selection of recreation activities.

The opinions of the individuals about "which faculty the recreation department should be in" do not make a difference on the mean score values of the "general scale" and its sub-dimensions ( $p>0.05)$. It does not differ whether it is in a sports science faculty or a tourism faculty. Since the course content of the recreation department in the universities is the same, there is no difference, no matter in which faculty recreation department is. In both faculties, recreation education is given in the best way and then it provides that people of all ages participate in activities in their leisure 
time. In other words, it motivates people and provides them to continue their lives in a healthy, peaceful and happy way.

Individuals' opinions about "how effective the games in recreational activities are", did not show any effect on the sub-dimension mean score values of "personal suitability" $(p>0.05)$. Considering the "guidance", "environment" sub-dimensions and the general scale, it was concluded that the mean score values of the individuals who think that the games in the activities are slightly effective were higher than the mean score values of the individuals who think that the games in the activities were very effective $(p<0.05)$. We can say that games are effective on individuals. Games are very important not only for individuals but also for children with disabilities. It is seen in Uzun (2020)'s study about the effect of hippotherapy on the life quality of children with autism that game is vitally important for children with autism. Game provides both physical and spiritual development of children. As these activities meet the basic needs of people, they are also very important for individuals with autism as they aim to lead a better life quality (Sarol, 2013).

According to the type of recreational activity that individuals do in their leisure time, the mean score values of the "general scale" and its sub-dimensions do not show a significant difference (p>0.05). We can state that the selection of recreational activity that all individuals do in their leisure time is the same. We can say that the expectations of individuals in their selection are the same. Therefore, we can say that the types of recreational activities in their leisure time are the same as the life quality is very important for individuals. So there is no difference between their participation in sports or other activities. They know that the more beneficial recreational activities they do in their leisure time, the healthier and longer they will lead their lives. The fact that the Personal Suitability Factor is the most important factor in students' selection of recreational activities supports our study (Yağmur, 2015; Yağmur, \& İçigen, 2016).

As a result, when the factors that affect students' selection of recreational activity type were examined, it was found that the highest factor was "appropriate for age". The statement with the lowest mean was "healthy life programs on TV". In addition, it was found that in the selection of individuals' recreational activities, the most effective factors were that the activities were personally suitable for them and the environment was also suitable.

Conducting the study in only one faculty restricts the study area. Considering these limitations, it may be possible to reveal the differences between the study groups by reaching a larger study group in the selection of the type of recreational activity.

\section{References}

Arslan, S. (1996). Yükseköğretim kredi ve yurtlar kurumuna bağlı yurtlarda kalan bayan öğrencilerin boş zamanlarını değerlendirme sorunları üzerine bir araştırma (Ankara ili örneği), Yüksek Lisans Tezi, Gazi Üniversitesi, Sağlık Bilimleri Enstitüsü, Ankara.

Arslan, S. (2010). Yetişkin Kent Halkının Belediyelerin Serbest Zaman Eğitimi ile Rekreasyon Faaliyetlerinin Sunumuna ve Yaşam Kalitesine Etkisine İlişkin Görüşleri (Ankara Büyükşehir Belediyesi Örneği). Doktora Tezi, Ankara Üniversitesi Eğitim Bilimleri Enstitüsü, Ankara.

Arslan, S. (2012). Kentli Bireylerin Rekreasyon Tercihlerini Etkileyen Faktörlerin Analizi: Ankara Büyükşsehir Belediyesi Örneği, International Refereed Academic Social Sciences Journal, 3 (7): 129 - 136.

Bucher, C.A., Bucher, R.D. (1974). Recreation for Today’s Society. New Jersey: Frentice-Hall.

Gül,T. (2014). Rekreasyon Olgusuna Genel Yaklaşım. 1.Bask1, S. 1-67. Ankara: Detay Yayınc1lik.

Hazar, A. (2009). Rekreasyon ve Animasyon, Detay Yayıncılık, Ankara.

Jenkins, J. M., Pigram, J. J. (2006). Outdoor Recreation Management. Routledge. S: 8 - 25.

Kurar, İ., Baltacı, F. (2014). Halkın Boş zaman değerlendirme Alışkanlıkları. Alanya Örneği, International Journal of Science Culture and Sport, , SI(2):39-52).

Mannell, R. C. (2007). Leisure, health and well-being. World Leisure Journal, 49(3), 114-128.

Sarol, H. (2013). Uyarlanmış Rekreasyonel Fiziksel Aktivitenin Otizmli Bireylerin Yaşam Kalitesi Üzerine Etkisi (Doktora Tezi). Gazi Üniversitesi, Sağlık Bilimleri Enstitüsü, Ankara. 
Schwilgin, F. A., Arch, B., \& Arch, M. (1974), Town planning guidelines, Canada.

Sönmezoğlu, U., Polat., E, \& Aycan, A.(2014). Gençlik Merkezi Üyeleri ve Bazı Değişkenlere Göre Serbest Zaman Tatmin Düzeyleri. International Journal of Science Culture and Sport, 2(1); 219-29.

Torkildsen, G. (1999). Leisure and Recreation Manegement. (T. A. Group, Dü.) London, GBR: Spon Press. S: $47-59$.

Türkmen, M., Kul, M., Genç, E., \& Sarıkabak, M. (2013). Konaklama işletmesi yöneticilerinin rekreasyon alg1 ve tutumlarının değerlendirilmesi: Batı Karadeniz Bölgesi Örneği. Electronic Turkish Studies, 8(8), 2139- 2152.

Uğurlu, A. (2005). Rekreasyonel Amaçlı Doğa Sporlarının Turizm'de Kullanılması Antalya Köprülü Kanyon Rafting Uygulaması. Yüksek Lisans Tezi, Akdeniz Üniversitesi, Antalya.

Uzun, M. (2020). Otizmli Çocukların Yaşam Kalitesinde Hippoterapinin Etkisi, Efe Akademi Yayınevi, İstanbul.

Uzun, M., İmamoğlu, O., Yamaner, F., Deryahanoğlu, G., \& Yamaner, G. (2017). Examination of the factors which prevent to participate the recreative activities: Example of girls high school. Journal of Human Sciences, 14(1), 950-962.

Yağmur, Y. (2015). Üniversite Öğrencilerinin Sosyalleşme Süreci ve Rekreasyon Aktivitelerinin İncelenmesi: Erciyes Üniversitesi Örneği. Yüksek Lisans Tezi, Akdeniz Üniversitesi, Sosyal Bilimler Enstitüsü, Antalya.

Yağmur, Y., İçigen, E.T. (2016). Üniversite öğrencilerinin sosyalleşme süreci ve rekreasyon faaliyetlerinin incelenmesi üzerine bir çalışma. Anatolia: Turizm Araştırmaları Dergisi, 27(2), 227-242. 